\title{
VIDIO SHARING SEBAGAI KIAT MENGAKTIFKAN SISWA DAN MENINGKATKAN HASIL BELAJAR PADA MASA PANDEMI COVID-19 BAGI SISWA SMA NEGERI 2 PINTU RIME GAYO
}

\author{
MURNIATI \\ SMA Negeri 2 Pintu Rime Gayo, Bener Meriah, Aceh \\ Email: murnijafri@gmail.com
}

\begin{abstract}
ABSTRAK
Pembelajaran di kelas sangat membutuhkan strategi maupun media yang tepat, efektif dan efisien. Sejalan dengan hal itu perlu adanya pembaharuan yang mengacu kepada upaya peningkatan keaktifan dan nilai kognitif siswa yang sebelumnya relative rendah. Hal ini dilihat pada pembelajaran materi Gerak Lurus, yang mungkin sulit dimengerti oleh siswa di tambah lagi adanya pengurangan alokasi waktu belajar tatap muka masa pandemi Covid 19. Media Pembelajaran Vidio sharing/youtube dapat menjawab tantangan dan menjadi salah satu alternative bagi guru untuk mengaktifkan siswa dan hasil belajar materi gerak lurus. Tujuan dari penelitian ini untuk mengetahui peningkatan prestasi belajar siswa tentang materi gerak lurus dan pengaruh penggunaan media vidio youtube terhadap keaktifan belajar siswa. dengan subjek penelitian siswa kelas X MIPA SMA Negeri 2 Pintu Rime Gayo. Melalui penelitian dua siklus diperoleh adanya kemajuan rerata hasil belajar siswa, dari 40,90\% di siklus 1, didapat peningkatan yang signifikan di siklus 2 yakni 86,36\%. Hasil rerata penilaian belajar dan jumlah siswa yang dinyatakan tuntas belajar pada setiap siklusnya yaitu siklus 1 nilai rerata 68,89 dengan jumlah siswa tuntas 9 dari 22 siswa. Untuk siklus 2 didapat rerata 85,19 dengan siswa yang tuntas 19 orang dari 22 siswa. Berdasarkan instrument amatan, dapat dinyatakan aktivitas siswa dalam proses pembelajaran Fisika dengan pembelajaran konstektual menggunakan media vidio youtube yang paling dominan adalah menonton secara seksama, mampu membuat ringkasan hasil yang di tonton, menyimak deskripsi yang diberikan guru serta bertukar pikiran antara siswa dengan guru dan siswa dengan siswa dengan nilai pada siklus I reratanya 74 dan di siklus II dengan rerata keaktifan peserta didik 82,92.
\end{abstract}

Kata Kunci: Media Pembelajaran, Vidio Youtube

\section{PENDAHULUAN}

Proses pembelajaran tatap muka di masa AKB New normal merupakan masa yang banyak ditunggu-tunggu para wali murid setelah beberapa bulan para peserta didik mengikuti pembelajaran daring yang dikontrol oleh para wali murid dari rumah. Namun dalam pelaksanaan nya tidak mudah menjalani proses pembelajaran ini karena siswa yang sudah lama tidak belajar tatap muka memiliki keaktifan belajar yang menurun dengan dalih dan alasan selama pembelajaran daring siswa tidak terlalu di tuntut untuk memahami materi dikarenakan sebagian peserta didik mengalami kendala pada jaringan internet serta ada beberapa siswa dan tua wali yang tidak memiliki hp android, Akibat dari itu keaktifan siswa selama daring hanya $50 \%$ saja, ini terlihat dari jumlah siswa yang masuk pembelajaran daring dan jumlah siswa yang hanya $50 \%$ 
mengumpul tugas yang di berikan guru. Selain turunnya keaktifan belajar siswa dalam proses belajar mengajar tatap muka masa AKB New Normal kendala yang di alami adalah berkurangnya alokasi waktu dalam satu jam pelajaran yaitu yang biasanya $1 \mathrm{x}$ 45 menit, dimasa AKB New Normal ini berkurang menjadi 1 x 30 menit sehingga untuk menuntaskan satu pokok bahasan para guru mengalami kesulitan akibat alokasi waktu yang berkurang. Untuk menyiasati kurangnya keaktifan belajar siswa guru dapat merancang model dan media pembelajaran yang aktif dan menyenangkan karena selama ini peneliti hanya menggunakan media pembelajaran sederhana contohnya, media power point yang mana guru hanya menjelaskan dari tayangan slide yang telah dipersiapkan.

Untuk memecahkan masalah di atas diperlukan pemilihan media pembelajaran yang menarik dan juga efesien dari segi waktu. Selain menarik dan efesien tetapi juga harus melaksanakan protokol kesehatan untuk tetap menjaga jarak dalam pelaksanaan proses belajar mengajar masa pandemi covid 19. Media vidio youtube adalah alternative yang menjawab tantangan yang ada karena vidio youtube sangat familiar di kalangan peserta didik dan dapat dijadikan sebagai pengganti guru mengajar untuk menyiasati kekurangan alokasi waktu jam tatap muka. Selain itu vidio youtube dapat dipilih dengan ragam model yang sesuai dengan materi yang kita sajikan dan dalam penayangan nya vidio ini sangat menarik dan tidak membosan kan, sehingga siswa tertarik untuk mengikuti pelajaran yang akan mereka lakukan. Vidio yuotube ini di bagikan kepada siswa pada malam hari sehari sebelum pelaksanaan proses belajar mengajar berlangsung, setelah siswa menonton tayangan vidio youtube siswa di berikan tugas menulis kesimpulan/meringkas isi vidio sharing kegiatan belajar. Sedangkan besoknya pada saat kegiatan belajar dikelas guru dan peserta didik hanya tinggal mengulang sedikit dan memberikan penguatan pada konsep-konsep yang di anggap perlu. Setelah siswa memahami konsep dari penayangan vidio youtube siswa di berikan LKPD yang berkaitan dengan vidio youtube yang telah mereka tonton sebelumnya dan setelah itu mempresentasekan secara klasikal didepan kelas. Di akhir pertemuan guru dapat memberikan latihan sesuai materi yang ada untuk mengetahui kemampuan siswa memahami materi yang di sajikan.

"Media komponen sumber belajar atau wahana fisik materi instruksional di lingkunga siswa yang dapat merangsang siswa untuk belajar" (Azhar Arsyad, 2010). Berdasarkan definisi tersebut, maka dapat disimpulkan media adalah alat yang memudahkan guru untuk menyampaikan materi yang akan disampaikan kepada siswa sehingga materi tersebut dapat menarik minat dan keaktifan belajar siswa. Dalam penyampaian materi yang diberikan guru media pembelajaran dapat membantu siswa meningkatkan pemahaman, menyajikan data dengan menarik dan terpercaya.

Media pembelajaran memiliki tiga manfaat yang penting jika dipakai oleh orang, sekelompok orang atau dalam kuantitas banyak orang, yaitu (1) memberikan semangat bagi penontonnya (2) memberikan informasi (3) menyajikan petunjuk (Kemp \& Dayton (Arsyad,2014). Menurut (Arsyad,2014) manfaat menggunakan alat bantu mengajar didalam kegiatan belajar mengajar sebagai menyampaian info dan fakta sehingga dapat mempercepat langkah-langkah mengajar, memfokuskan perhatian anak, menangani keterbatasan indera, ruang, dan waktu. Alat bantu mengajar dapat juga menyampaikan kesamaan pengalaman kepada siswa tentang kejadian yang 
terjadi dilingkungan mereka. Youtube sebagai alat bantu mengajar memiliki tujuan agar dapat membentuk situasi kegiatan belajar yang memikat, memuaskan dan memiliki daya tarik. Media ini bisa digunakan dalam kegiatan belajar di kelas, oleh peserta didik maupun guru.

Vidio sharing yang dimanfaatkan untuk alat belajar memiliki keunggulan yaitu: (1) Memberikan tambahan nilai terhadap pendidikan. (2) Sangat praktis sebab gampang dipakai serta bisa dicermati semua golongan. (3) Dapat sebagai sumber penjelasan mengenai kemajuan sains, informasi, kultur dan peradaban. (4) Berlaku saling aktif dalam menyediakan ruang konsultasi atau dialog serta meresensi vidio kegiatan belajar. (5) Dapat dibagikan melalui link HTML, Embed kode video kegiatan belajar yang dapat di bagi melalui sosial media (FB, twitter, blog/website). (5) Bersifat murah karena mudah di akses secara gratis untuk semua kalangan.

Guru harus dapat mengetahui secara rinci bagaimana membuat simbul catatandi vidio cara mengunggah video kegiatan belajar di youtube agar dapat diakses oleh siapapun; Bagaimana cara mendapatkan video kegiatan belajar di vidio sharing sebagai tambahan ilmu pengetahuan; dengan cara apa mendapatkan video sharing dari youtube yang menggunakan perangkat atau tanpa non perangkat lunak; Bagaimana memutar video sharing belajar dalam jaringan atau tanpa jaringan; Bagaimana memadukan video pembelajaran dengan media lain sebagai bahan mengajar di kelas.

Pada perkembangan jaman sekarang ini telah banyak link vidio pembelajaran yang beredar di dunia maya yang sesuai dengan materi yang akan di ajar kan sehingga para siswa dapat mengakses link tersebut dengan mudah dan gratis. Selain mengakses vidio para pengguna youtube saat ini dapat juga meng upload, menonton, mensearch vidio bahkan berbagi klip vidio secara gratis. Hasil belajar merupakan tolak ukur akan keberhasilan bagi peserta didik tentang penguasaan sesuatu materi yang dipaparkan oleh guru. Hasil belajar ini dikatagorikan tiga yaitu: penilaian kognitif, afektif dan psikomotorik. Siswa mengalami keberhasilan belajar jika memiliki peningkatan nilai ke tiga aspek dari hasil pembelajaran sebelumnya.

Beberapa hasil penelitian menyatakan bahwa vidio pembelajaran sangat efektif dalam menaikkan hasil belajar dan minat serta keaktifan belajar siswa (Sofyan Hadi: 2017), (Diah Retno Anggraini), (Yuniarti, dkk;2015), (Dwi yunita, dkk;2017), (Nilam cahayani;2017) dan (Renda Lestari;2016),menyatakan bahwa: (a) Vidio pembelajaran sangat menyenangkan dan tidak membosankan. (b) Vidio pembelajaran dapat berperan sebagai penghantar informasi yang diberikan guru kepada siswa. (c) Vidio pembelajaran dapat ditonton secara berulang-ulang sehingga siswa menjadi paham tentang materi yang disampaikan. (d) Media vidio pembelajaran dapat mempengaruhi terhadap keaktifan dan hasil belajar siswa. (e) Vidio youtube sangat bervariatif sehingga para pengguna dapat memilih sesuai materi yang disajikan. (f) Vidio youtube sangat merangsang ide guru sehingga meningkatkan kreatifitas pembelajaran di kelas. (g) Vidio pembelajaran dapat memenuhi kebutuhan cara belajar siswa yang berbedabeda. 


\section{METODE PENELITIAN}

Metode penelitian ini adalah PTK (Penelitian Tindakan Kelas). Penelitian ini menggunakan 2 siklus yang setiap siklus terdiri dari dua kali pertemuan. Tahapan pada setiap siklus yaitu tahap perencanaan, pelaksanaan tindakan, pengamatan dan refleksi. Populasi penelitian ini seluruh siswa kelas X MPA Tahun Pelajaran 2020/2021. Dengan subjek penelitian siswa kelas X MIPA Tahun Pelajaran 2020/2021 yang berjumlah 22 siswa terdiri dari 06 siswa putra dan 16 siswa putri.

Pengumpulan data diperoleh dari tiga jenis data masukan yaitu: dengan mengambil data hasil pengamatan dalam pembelajaran, data hasil observasi siswa dalam mengikuti pembelajaran, wawancara dengan teman sejawat serta hasil evaluasi akhir pada proses belajar mengajar.

Data yang dikumpulkan dalam pelaksanaan PTK adalah : (a) Data kuantitatif yaitu data yang diperoleh melalui tes penguasaan materi yang berupa nilai siswa dalam setiap siklus. Pada siklus I tes tulis berbentuk pilihan ganda dengan jumlah soal 6 buah dan esay berjumlah 3 buah. Pada siklus II bentuk soal esay dengan jumlah soal sebanyak 6 buah soal. (b) Data kualitatif merupakan data yang diperoleh melalui observasi (pengamatan) langsung terhadap jalan nya proses pembelajaran. Data kualitatif diperbolehkan melalui instrumen pengamatan yang dapat berbentuk angket, lembar isian, pedoman wawancara dan sebagainya.

\section{HASIL DAN PEMBAHASAN}

Hasil observasi diperoleh dari beberapa amatan yakni: supervisi administrasi pelaksanaan mengajar, instrumen telaah RPP, supervisi kegiatan pembelajaran menggunakan media vidio youtube, dan observasi aktivitas siswa selama kegiatan proses belajar mengajar berlangsung.

Data tes formatif untuk mengetahui peningkatan kemampuan memahami materi gerak lurus (jarak dan perpindahan Siklus I) dan (Gerak Lurus Siklus II) adalah sebagai berikut:

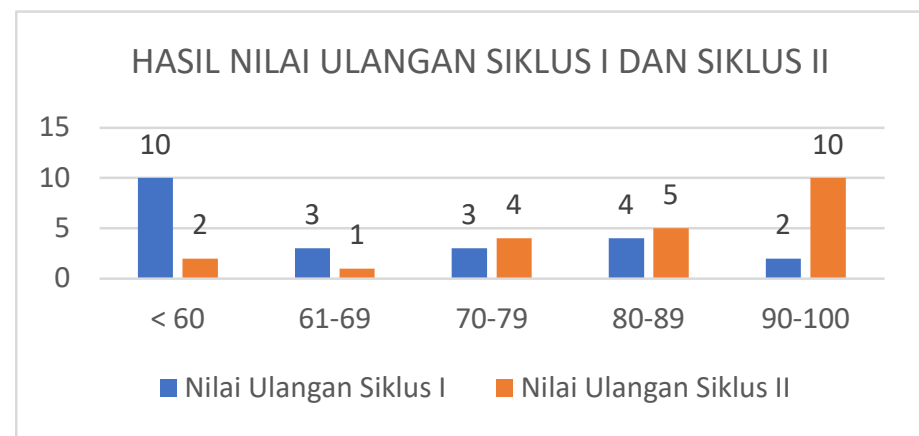

Grafik 1. Hasil Nilai Ulangan Siklus I dan II

Hasil pengamatan Observer yang mengamati jalannya kegiatan pembelajaran diperoleh data rerata hasil ulangan harian materi gerak lurus per-siklus adalah: 


\section{Rerata Ulangan Harian Per-Siklus}

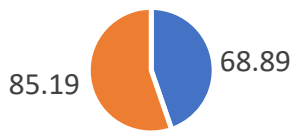

- Siklus I $n$ Siklus II

Grafik 2. Rerata Ulangan Harian Per-Siklus

Hasil penelitian pada kelas X MIPA dalam mengerjakan ulangan harian gerak lurus diperoleh grafik yang menunjukan ketuntasan peserta didik per-siklus sebagai berikut:

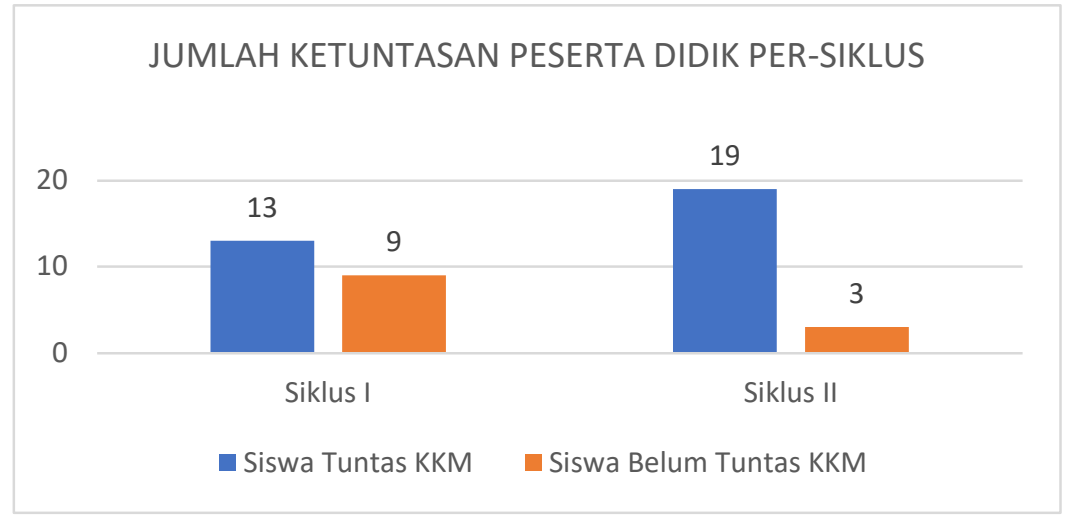

Grafik 3. Jumlah Ketuntasan Peserta Didik Per-Siklus

Sedangkan prosentase ketuntasan belajar peserta didik dapa dilihat pada grafik di bawah ini.

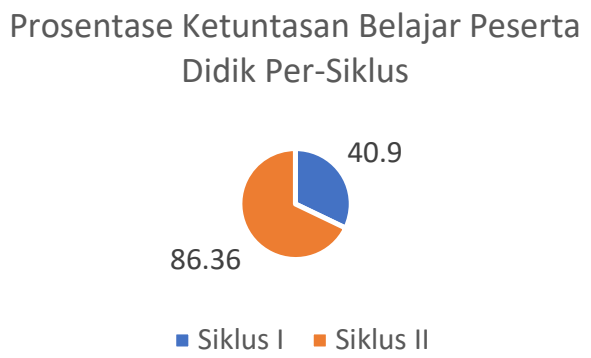

Grafik 4. Prosentase Ketuntasan Belajar Peserta Didik Per-Siklus

Dari grafik 1 s.d 4 diatas diketahui penggunaan alat bantu vidio youtube pada kegiatan pembelajaran gerak lurus didapatkan nilai ulangan harian siklus II mengalami peningkatan dibandingkan nilai ulangan pada siklus I. rerata kemampuan peserta didik untuk materi gerak lurus (jarak dan perpindahan di siklus I) sebesar 68,89 dan rerata 
di siklus II dengan materi gerak lurus sebesar 85.19. Di siklus I peserta didik yang tuntas hanya 13 orang dari 22 peserta didik yang mengikuti pembelajaran dengan prosentase ketuntasan belajarnya sebesar 40,90\%. Pada siklus II ketuntasan belajar peserta didik mengalami peningkatan menjadi 19 orang dari 22 peserta didik yang mengikuti pembelajaran atau memiliki prosentase ketuntasan belajar nya sebesar 86,36 $\%$. Perbedaan ini terjadi dikarenakan pada siklus I peserta didik masih merasa asing dan kurang fokus dalam menonton vidio youtube sehingga dalam membuat kesimpulan hasil yang di tonton belum sesuai yang diharapkan. Selain itu ada beberapa siswa yang tidak mempunyai HP android yang mengakibatkan mereka tidak memiliki kesimpulan dari vidio pembelajaran.

Sedangkan pada siklus II mengalami peningkatan nilai ulangan harian dikarenakan peserta didik bisa leluasa menonton materi yang telah ada kapan pun dan dimanapun mereka berada, sehingga mereka bisa mengulang vidio pembelajaran youtube berulang-ulang selain itu Di siklus II guru bidang studi memberikan pinjaman perangkat tablet belajar milik sekolah kepada peserta didik untuk di pakai dalam pembelajaran sehingga para peserta didik dapat seluruhnya menonton dan membuat kesimpulan dari vidio yang dibagikan.

Data kualitatif pada penelitian ini diperoleh dari data pengamatan (observasi) pelaksanaan Kegiatan pembelajaran yang diambil dari instrument pengamatan yaitu sebagai berikut:

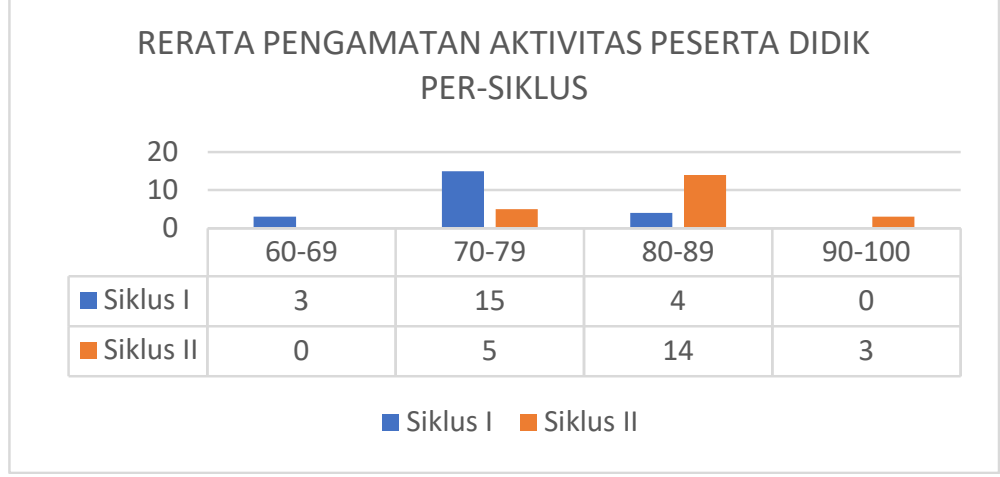

Grafik 5. Rerata Pengamatan Aktivitas Peserta Didik Per-Siklus

Dari grafik 5 didapatkan bahwasanya keaktifan belajar peserta didik mengalami peningkatan dari siklus I. rerata keaktifan siswa kelas X MIPA siklus I adalah 74 sedangkan di siklus II rerata keaktifan belajar siswa materi gerak lurus adalah 82,92.

Perbaikan kekurangan siklus I dilakukan pada siklus II untuk memperbaiki kegiatan belajar fisika materi gerak lurus dengan menggunakankan media vidio youtube. Pada Siklus II didapatkan kegiatan belajar telah mengalami peningkatan sehingga dapat dikatakan proses pembelajaran berkategori baik. Hal ini karena siswa sudah leluasa menonton vidio pembelajaran youtube secara berulang-ulang di rumah sebelum kegiatan belajar berlangsung keesokan harinya. Di Kegiatan belajar menggunakan media vidio youtube mengharuskan peserta didik menonton dan membuat ringkasan hasil tontonan tersebut secara langsung yang mengakibatkan daya ingat siswa menjadi lebih lama karena alat indera yang digunakan siswa ketika belajar difungsikan secara berbarengan. Karena Siklus II telah berjalan dan menghasilkan nilai 
ulangan yang bagus dan telah tuntas secara klasikal maka penelitian ini tidak perlu di lanjutkan ke siklus III.

Pengkajian: (a) Tuntas Belajar Peserta Didik Melalui kajian ini diperoleh belajar secara konstektual menggunakan vidio youtube berpengaruh positif untuk meningkatkan keaktifan dan hasil belajar siswa. Hal ini terlihat dari tingkat pemahaman peserta didik yang baik pada konsep yang diajarkan guru selama kegiatan ini (keterampilan peserta didik membaik dari siklus 1 ke 2) yaitu 40,90\% dan 86,36\%. Di siklus 1ni secara klasikal pesrta didik dinyatakan tuntas. (b) Keterampilan guru dalam mengelola kelas. Dari analisa data, didapatkan aktivitas peserta didik dalam kegiatan pembelajaran konstektual menggunakan media vidio yuotube dalam setiap siklus mengalami peningkatan. Hal ini berdampak positif terhadap proses kemampuan kognitif dan sikap siswa dalam menerapkan konsep gerak lurus, yakni terlihat dengan peningkatan keaktifan rerata peserta didik di setiap siklus yaitu dari siklus I reratanya 74 menjadi 82,92 di siklus II. Sehingga pengurangan waktu karena adanya pandemi covid 19 tidak lah menjadi kendala dalam menyelesaikan pokok bahasan di kelas. (c) Kegiatan guru dan peserta didik dalam kelas dari analisa data, ditemukan kegiatan peserta didik selama pembelajaran Fisika melalui pembelajaran konstektual menggunakan vidio youtube yang cenderung ada menonton secara seksama, mampu membuat ringkasan hasil yang di tonton serta menyimak paparan dari guru, diskusi sesama peserta didik juga peserta didik dengan guru. Ini menggambarkan kegiatan tersebut di katagorikan aktif. Sementara kegiatan guru yaitu melalui langkah-langkah PBM yang baik, dapat terlihat dari aktivitas: memberi penguatan pada materi yang telah di tonton, mengarahkan dan mendampingi peserta didik mengerjakan LKPD, mengarahkan siswa membuat kesimpulan yang telah disepakati.

\section{KESIMPULAN DAN SARAN}

Dari penelitian yang telah dilaksanakan selama dua siklus juga melalui pembahasan/analisis dapat disimpulkan: (a) Pembelajaran konstektual menggunakan vidio youtube berdampak positif terhadap peningkatan keaktifan dan nilai peserta didik yang terlihat dari tingkat tuntasnya pada setiap siklus, yakni 40,90\% dan (86,36\%). (b) Penerapan pembelajaran konstektual menggunakan vidio youtube memiliki dampak positif, yakni meningkatnya keaktifan dan semangat belajar peserta didik dapat dilihat melalui rerata keaktifan belajar siswa di siklus I sebesar 74 meningkat menjadi 82,92 di siklus II serta statemen wawancara sikap siswa yang menyatakan bahwa siswa tertarik dan berminat dengan pembelajaran konstektual menggunakan vidio youtube. (c) Pembelajaran konstektual menggunakan vidio youtube memiliki pengaruh positif terhadap kemampuan kognitif peserta didik terhadap materi yang disampaikan.

Dari hasil penelitian yang telah dilaksanakan, kegiatan mengajar lebih sesuai serta cenderung mendapatkan hasil yang baik walaupun adanya pengurangan alokasi waktu setiap jam nya. Untuk itu penulis menyarankan agar: (a) Pelaksanaan pembelajaran menggunakan vidio youtube membutuhkan kesiapan yang maksimal terutama menetapkan vidio yang akan di tayangkan. Selain menarik vidio harus dipilih kekinian dan sesuai dengan kurikulum, sehingga para siswa lebih mudah memahaminya dan tidak membosan kan dalam menonton tayangan tersebut. (b) Sehubungan dengan 
upaya peningkatan prestasi peserta didik dalam menerapkan konsep gerak lurus melalui vidio youtube, guru hendaknya lebih sering mencari vidio yang inovatif dan dapat membuat vidio pembelajarn sendiri sehingga siswa lebih familiar, dapat bereksplorasi menambahwawasan baru, menemukan konsep dan memiliki keterampilan, yang pada akhirnya mampu mengaplikasikan dalam kehidupan seharihari. (c) Diperlukan penelitian yang berkesinambungan, karena penelitian ini hanya pada subyek kelas X MIPA SMA Negeri 2 Pintu Rime Gayo.

\section{DAFTAR PUSTAKA}

Arikunto, Suharsimi.2019. Prosedur Penelitian.Jakarta:Rineksa Cipta

Ali, Muhammad.1996.Guru Dalam Proses Belajar Mengajar.Bandung: Sinar Baru Algesindo

Cahayani,Nilam. 2017.Penggunaan media pembelajaran vidio youtube untuk meningkatkan minat dan hasil belajar menggambar ilustrasi siswa di kelas VIIIE SMP Negeri 1 Padang. Link url: http://ejournal.unp.ac.id/index.php/serupa/article/download/8329/6407.tang gal: 20 Oktober 2020

Hadi Sofyan.2017.Efektivitas penggunaan vidio sebagai media pembelajaran untuk sekolah dasar.Prosiding TEP \& PDs.nomor 15; hal 96-102. Link url: http://pasca.um.ac.id/conferences/index.php/sntepnpdas/article/view/849. Tanggal 10 Oktober 2020

Kanginan, Marthen. 2018, Fisika SMA Kelas X. Jakarta: Penerbit Erlangga

Lestari Randa. Penggunaan youtube sebagai media pembelajaran Bahasa inggris.seminar nasional Kedua Pendidikan Berkemajuan dan Menggembirakan; Hal:607-612. url: https://publikasiilmiah.ums.ac.id/bitstream/handle/11617/9566/68.pdf?sequ ence $=1 \&$ isAllowed $=y$ Tanggal: 10 Nopember 2020

Supiyanto. 2018. Fisika SMA Kelas X. Bandung: penerbit Ganexa Excak Bandung Yunita Dwi, Wijayanti Astuti.2017.Pengaruh media vidio pembelajaran terhadap hasil belajar IPA ditinjau dari keaktifan siswa.jurnal LP3M.Vol 3;hal:153160.link url:https://jurnal.ustjogja.ac.id/index.php/sosio/article/download/1614/753.t anggal 10 Oktober 2020. 